\title{
THE EFFECT OF DIFFERENT CONCENTRATIONS OF SODIUM CHLORIDE ON SURVIVAL OF LISTERIA MONOCYTOGENES IN WHITE SOFT CHEESE
}

\author{
AMANI LOTFY F.A. HEMA*, NERMEEN H.M. HASSANEEN ${ }^{*}$ and \\ AMAL ALI SHEHATA** \\ *Bacteriological Unit, Animal Health Research Institute, Nadi El-Said Str., Dokki, Giza, Egypt. \\ ${ }^{* *}$ Bacterial Toxin Unit, Food Hygiene Department, Animal Health Research Institute, Nadi El-Said \\ Str., Dokki, Giza, Egypt.
}

\section{ABSTRACT}

Received at: $25 / 3 / 2012$

Accepted: 9/4/2012
The intrinsic characteristics of soft cheeses are perfect for L. monocytogenes growth because they are slightly acidic, have a high moisture content and a high water activity, and have a high fat content which can play a protective role for the organism against control treatments, and also because they contain high amounts of available nutrients. Thus the study aimed to determine the effect of different salt concentration (zero, $10 \%, 15 \%$ and $20 \%, \mathrm{w} / \mathrm{v}$ ) at different storage time ( zero , 7,15 , 30,60 and 90 ) days on survival of $L$. monocytogenes artificially contaminated in manufactured soft white cheese. Results revealed that addtion of $\mathrm{NaCl}$ at concentration of $15 \%$ for at least 30 days or $20 \%$ for 15 days during cheese manufacturing and storage at $4^{\circ} \mathrm{C}$ could prevent survival of $L$. monocytogenes before consumption of cheese.

Keywords: White cheese, L. monocytogenes, Sod.Chloride concentration.

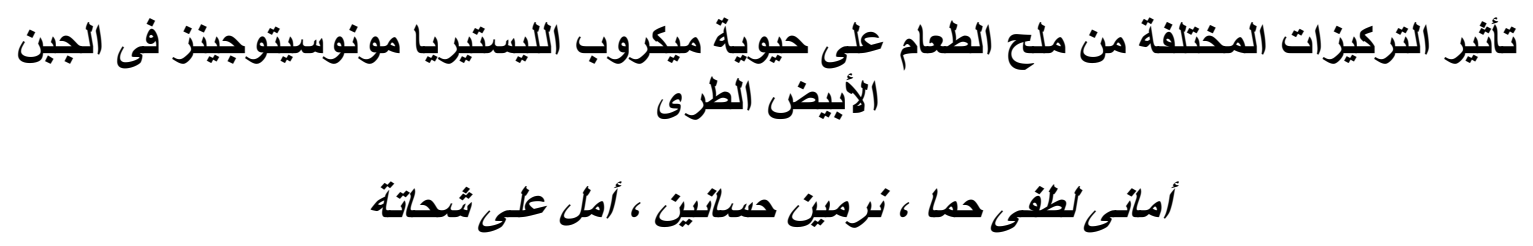

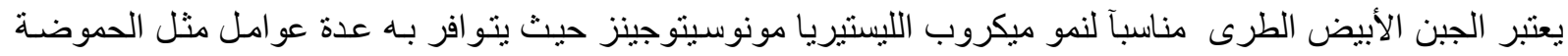

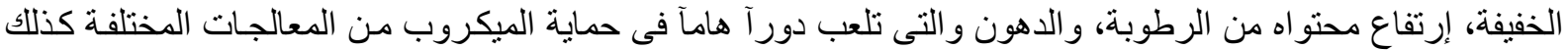

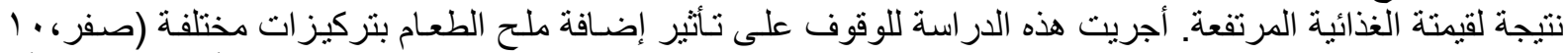

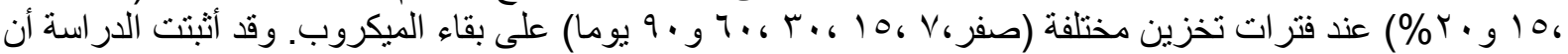

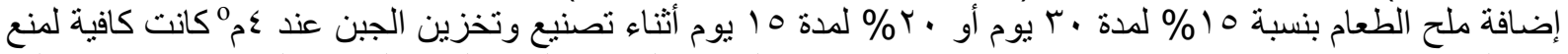

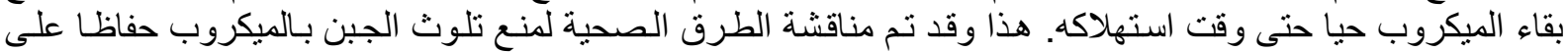




\section{INTRODUCTION}

Listeria monocytogenes has become pathogen of concern for the food industry since documentation of its association with serious outbreaks of food borne illness (Schuchat et al., 1991). Listeria monocytogenes multiplies over a wide range of temperature from 3 to $45^{\circ} \mathrm{C}$ and it is considered as psychrotolerant foodbrone pathogen. It grows over a $\mathrm{pH}$ range of 5 to 9.6 and salt concentration as high as $25.5 \%$ at $4^{\circ}$ $\mathrm{C}$ and can cause infections in animals and humans and has been recognized as a significant foodborne pathogen for the past decade. The infections can be acute and severe causing meningitis with mortality up to $30 \%$ in susceptible individuals as elderly, infants and immunocompromised people and can lead to abortion (Lund, 1990 and leuschner and Ilsch, 2003).

Foodborne illness associated with L. monocytogenes presents a major public health concern throughout the world (Hall, 1997). Major foodbrone outbreaks involved dairy products has been attributed to consumption of pasteurized milk (Fleming et al., 1985), Mexican style soft cheese (James et al., 1985), ice cream (Donnelly et al., 1987) and Swiss regional type soft cheese (Bille and Glauser, 1988).

Raw milk can be contaminated either by L. monocytogenes from the dairy environment or during the milking process from mastitic udder. Contamination of soft cheese can occur during manufacture or postproduction. The ubiquity of the organism and its ability to multiply in damp and cool conditions presents a problem in controlling post-production contamination even under good hygienic conditions (Harver and Gilmour 1992, Sanchz-rey et al., 1993). Leuschner and Boughtflower (2002) found that if the milk was contaminated with L. monocytogenes before the cheese making process, it could survive the manufacture process and existed in the cheese at constant concentrations for up to four weeks.
The salting process is an important step in the manufacture of most cheese varieties. The salt in cheese has different functions, such as reduction of curd moisture, suppression of unwanted microorganisms, modification of flavor, texture and contribution to cheese ripening (Ibanez et al., 1993; Laborda and Rubiolo 1999; Mullet et al., 1999). Therefore, in cheese making processes of some traditional cheese varieties, a high salt content in brine is essential for controlling micro flora, preventing growth of pathogens and controlling enzyme activities during storage (Abd El-Salam et al., 1993). Numerous studies have shown that the survival or growth of L. monocytogenes depends on the conditions during manufacture (Gameiro et al., 2007). L. monocytogenes could survive in brine, if salt concentration was not higher than 19\% (Durmaz et al., 2009). The necessity of Sodium salts, particularly Sodium chloride, for the production of safe, wholesome foods and the key literature on the antimicrobial properties of sodium chloride in foods should be reviewed to address the impact of salt and sodium reduction or replacement on microbiological food safety and quality (Taormina, 2010).

This study was planned to study the effect of different concentrations of Sodium Cloride on survival of $L$. monocytogenes during manufacture and storage of soft white cheese

\section{MATERIALS and METHODS}

Inoculum preparation: L. monocytogenes (NCTC 7973/ATCC35152) used in this study was obtained from the reference strain bank of Food Hygiene Department-Animal Health Research Institute (AHRI), Doki, Giza. The strain was deep frozen stored in a cryoprotectant vial at $\left(-30^{\circ} \mathrm{C}\right)$. An inoculum of the pathogen was grown in Tryptic Soy Broth for overnight at $35^{\circ} \mathrm{C}$. Cells were centrifuged for $10 \mathrm{~min}$ at $8000 \mathrm{rpm}$. Supernatant was discarded and cells were washed three times and re-suspended in sterile $0.1 \%$ peptone water. The cells were (diluted in peptone water) adjusted to obtain the desired inoculum level $\left(1-3 \times 10^{9}\right) \mathrm{CFU} / \mathrm{ml}$ 
before addition to the pasteurized milk for soft cheese production.

Preparation and inoculation: Cheese samples were prepared according to the traditional method by dissolving the appropriate quantity of $\mathrm{NaCl}$ in pasteurized milk. Different quantities of $\mathrm{NaCl}$ were added to obtain the required concentrations (zero, 10\%, 15\% and $20 \%, \mathrm{w} / \mathrm{v})$, respectively and were dispensed into $1000 \mathrm{~mL}$ sterile beakers. Beakers were located in controlled water bath at $47^{\circ} \mathrm{C}$. Samples were separately inoculated by $1 \mathrm{ml}$ of L. monocytogenes inoculum to obtain a level of $\left(10^{6} \mathrm{CFU} / \mathrm{ml}\right)$. Rennet was added to inoculated milk samples and were left in a water bath till the curd formation. Cheese curds were aseptically filtered from their original whey and added to previously prepared and autoclaved brine solutions (zero, $10 \%, 15 \%$ and $20 \%, \mathrm{w} / \mathrm{v})$ respectively to put aside the effect of the contaminated cheese brine on survival of L. monocytogenes in the manufactured cheese. Cheese samples were stored at $4^{\circ} \mathrm{C}$ for 90 days (experiment time) and were sampled at zero, 7, 15, 30, 60 and 90 Days. Samples containing Zero, 10\%, 15\% and $20 \% \mathrm{NaCl}$ were abbreviated as $\mathrm{C} 1, \mathrm{C} 2$, $\mathrm{C} 3$, and $\mathrm{C} 4$, respectively.

Ten $\mathrm{ml}$ of milk samples of each $\mathrm{NaCl}$ concentration before curd formation and also ten gm of cheese samples from each $\mathrm{NaCl}$ concentration samples were obtained and homogenized with $90 \mathrm{~mL}$ of $0.1 \%$ sterile peptone water for $2 \mathrm{~min}$ in stomacher. From this basic dilution, a series of decimal dilutions were prepared for microbiological analysis according to APHA (2001). Typical colonies of $L$. monocytogenes, which exhibited a black color, were enumerated by surface plating on Oxford agar (Oxoid) containing Listeria selective supplement (Oxoid) after an incubation period of $48 \mathrm{~h}$ at $35^{\circ} \mathrm{C}$. Five selected colonies were confirmed by streaking cultures onto TSA and isolated colonies were tested according to (FDA, 2003) for the following characteristics:

Catalase production, carbohydrate fermentation (maltose, dextrose, mannitol, xylose and rhamnose), umbrella motility in SIM medium at $25^{\circ} \mathrm{C}$, -hemolysis and Gramstaining. When the organism was not detected by direct plating, then $25 \mathrm{~mL}$ of the samples were added in $225 \mathrm{~mL}$ of Listeria enrichment broth (LEB, Oxoid), enriched at $30{ }^{0} \mathrm{C}$ for 48 $h$ and retested for the presence of L. monocytogenes using the previously described procedures for plating on Oxford agar and confirming tests.

The results were statistically analyzed using SPSS for Windows version 16. "SPSS Inc. Headquarters, Chicago, Illinois USA.".

Table 1: Effect of sodium chloride concentration on the Survival of L. monocytogenes in white soft cheese.

\begin{tabular}{lcccccc}
\hline Concentration & Zero & $10 \%$ & $15 \%$ & Detection & $20 \%$ & Detection \\
\hline Zero & & & & & & \\
\hline 7 day & $7 \times 10^{6 \mathrm{~A}^{*}}$ & $6.6 \times 10^{6 \mathrm{~A}^{*}}$ & $4 \times 10^{6 \mathrm{~A}^{*}}$ & ND & $2.8 \times 10^{6 \mathrm{~A}^{*}}$ & ND \\
\hline 15 day & $6.4 \times 10^{6 \mathrm{Ab}^{*}}$ & $6.2 \times 10^{6 \mathrm{Ab}^{*}}$ & $4 \times 10^{4} \mathrm{ab}^{* *}$ & $\mathrm{ND}$ & $1 \times 10^{3 \mathrm{~B}^{* *}}$ & $\mathrm{ND}$ \\
\hline 30 day & $1 \times 10^{6 \mathrm{Ab}^{*}}$ & $6.5 \times 10^{6 \mathrm{Ab}^{*}}$ & $2 \times 10^{3} \mathrm{ab}^{* * *}$ & ND & Zero & -ve \\
\hline 60 day & $3 \times 10^{7 \mathrm{~A}^{*}}$ & $5.8 \times 10^{5 \mathrm{a}^{* *}}$ & Zero & $+\mathrm{ve}$ & Zero & -ve \\
\hline 90 day & $7.7 \times 10^{6 \mathrm{~A}^{*}}$ & $5.4 \times 0^{5 \mathrm{a}^{* *}}$ & Zero & $+\mathrm{ve}$ & zero & -ve \\
\hline
\end{tabular}

For rows: there is significant difference between cells have capital and its small letter

For columns: there is significant difference between cells have different numbers of $(*)$

ND: not done.

+ ve, -ve: detection after enrichment 


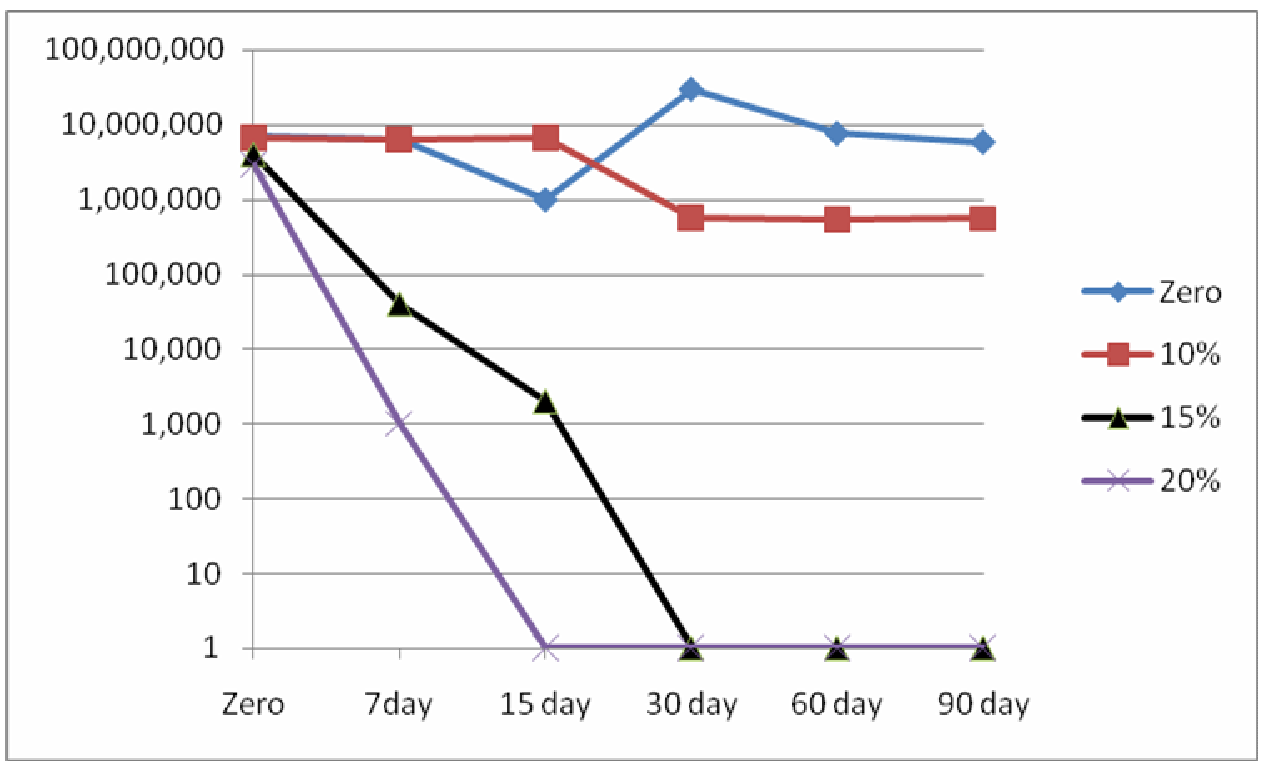

Fig. 1: Effect of sodium chloride concentration on the Survival of L. monocytogenes in white soft cheese

\section{RESULTS}

Results represented in Table 1 \& Figure 1 showed the effect of different concentrations of $\mathrm{NaCl}$ on the viability of L. monocytogenes during ripening and storage of soft white cheese at $4^{\circ} \mathrm{C}$.

It is worthy to mention that $L$.monocytogenes count in milk samples with different $\mathrm{NaCl}$ concentrations taken just after inoculation of the pathogen ranged from $1-4 \times 10^{6} \mathrm{CFU} / \mathrm{g}$ without any recorded significant differences. The population of L.monocytogenes at zero time (just after curd formation) in cheese samples with different $\mathrm{NaCl}$ concentrations were $7 \times 10^{6}, 6.6 \times 10^{6}, 4 \times 10^{6}$ and $2.8 \times 10^{6}$ $\mathrm{CFU} / \mathrm{g}$, respectively for the concentrations Zero (C1), 10\% (C2), 15\% (C3), and 20\% (C4).

Although the pathogen counts apparently decreased by the gradual increase of the $\mathrm{NaCl}$ concentration, this decrease was insignificant.

Concerning Zero $\mathrm{NaCl}$ concentration (C1) it was observed that the population of the pathogen increased slightly from $7 \times 10^{6}$ to 3 $\mathrm{x} 10^{7} \mathrm{CFU} / \mathrm{g}$ during storage and remained more or less constant throughout the rest of the storage time.

The addition of $10 \% \quad \mathrm{NaCl}$ (C2) had successfully reduced the contamination of
L.monocytogenes by one $\log$ at the end of storage time (90 days). A significant decrease $(\mathrm{P}<0.05)$ in L.monocytogenes counts was recorded from $\mathrm{C} 3$ compared to (C2). While in samples (C3) there was a marked and significant decrease $(\mathrm{P}<0.05)$ in the pathogen count from $4 \times 10^{6}$ to $4 \times 10^{4}$ and $2 \times 10^{3}$ at zero, $7^{\text {th }}$ and $15^{\text {th }}$ days of storage ,respectively until the pathogen failed to be detected by direct plating after 30 days storage. However, all samples were positive for L. monocytogenes after enrichment in LEB at the end of the storage period.

It was shown that the number of L. monocytogenes in (C4) was significantly decreased $(\mathrm{P}<0.05)$ from $2.8 \times 10^{6}$ to zero on the $15^{\text {th }}$ day but it could be detected by direct plating on $7^{\text {th }}$ day $\left(1 \times 10^{3} \mathrm{CFU} / \mathrm{g}\right)$. However the pathogen could not be detected at this concentration on the $15^{\text {th }}$ day of storage by both the direct plating $\&$ enrichment and thereafter.

\section{DISCUSSION}

The ability of L. monocytogenes to survive and grow at high salt concentrations and low temperature contributes to a potential health hazard after the consumption of contaminated 
milk and dairy products and often involved in sever listeriosis outbreaks and constitutes a great challenge to the dairy industry.

\section{Although the population of}

L.monocytogenes at zero time (just after curd formation) in cheese samples with different $\mathrm{NaCl}$ concentrations were apparently decreased by the gradual increase of the $\mathrm{NaCl}$ concentration, this decrease was insignificant $(\mathrm{P}<0.05)$. Meanwhile several investigators reported a significant drop in the pathogen count during cheese manufacturing procedures (Ryser et al., 1985; Dominguez et al., 1987; Kaufmann, 1990; Marth and Ryzer, 1990; Tawfik, 1993 and Hassan, 1996).

Inspite of the addition of $10 \% \mathrm{NaCl}$ (C2) had successfully reduced the contamination of $L$.monocytogenes by one $\log$ by the end of storage time, it could not be relied on for its weak effect and long time onset (90 days). These results agreed with Larson et al. (1999) who reported that L. monocytogenes survived for 118 days in fresh feta cheese brines (6.5 $\% \mathrm{~g} / \mathrm{L} \mathrm{NaCl}$ ) at $4{ }^{\circ} \mathrm{C}$ and $12{ }^{\circ} \mathrm{C}$, it has been shown that $L$. monocytogenes can grow in salt solutions of up to $6 \% \mathrm{~g} / \mathrm{L} \mathrm{NaCl}$. Many authors discussed that Sodium Chloride in concentration $1-7 \%$ did not inhibit the growth of L.monocytogenes (Pipova et al., 2002). Moreover others stated that Cheese which made from raw milk with high salt level over $10 \%$ if contaminated with L. monocytogenes could be unsafe Papageorgiou and Marth (1989), Abdalla et al. (1993) and Hassan, (1996).

It is then strongly considered one of the potential difficulties to control L. monocytogenes in food because of the apparent salt resistance of the pathogen (up to $10 \%$ sodium chloride) (Pearson and Marth 1990).

For samples (C3) the obtained results showed a marked and significant decrease $(\mathrm{P}<0.05)$ in the pathogen count until the pathogen failed to be detected by direct plating after 30 days storage, meanwhile, all samples were positive for L. monocytogenes after enrichment which can be attributed to the partial injury of the cells with the increase of $\mathrm{NaCl}$ concentration and length of storage time.

In a work conducted by Papageorgiou and Marth (1989) to study the fate of L. monocytogenes in salted whey. The authors found that the pathogen was able to grow in salted whey $(6 \% \mathrm{~g} / \mathrm{L})$, but was inhibited by a salt concentration of $12 \% \mathrm{~g} / \mathrm{L} \mathrm{NaCl}$ in the whey which is more or less inconsistent with the obtained results.

The extreme decrease of $L$. monocytogenes population while retaining its ability to be detected by direct plating till the $7^{\text {th }}$ day and by enrichment until before the $15^{\text {th }}$ day of storage at $4{ }^{\circ} \mathrm{C}$ in concentration as high as $20 \%$ (C4) was interestingly explained by other researchers as the environmental stresses such as low temperature and sodium chloride may lead to sublethally injured microorganisms. These sub-lethally injured microorganisms are viable, but they are physiologically deficient. Under favourable growth condition injured cells can repair and regain their pathogenicity (Ray, 1984).

In this concern, Durmaz et al. (2008) recorded that L.monocytogenes was destroyed at $19 \% \mathrm{NaCl}$ concentration after7 days of storage at $4{ }^{\circ} \mathrm{C}$. On the other hand, Miller et al. (1997) reported that L. monocytogenes survived for 30 days at $12^{\circ} \mathrm{C}$ in brine containing $20 \% \mathrm{NaCl}$. The authors indicated that low temperatures and high salt concentrations are not enough to prevent the survival of this pathogen. Also, Hefnawy and Marth (1993) examined survival of L. monocytogenes in different concentration of $\mathrm{Nacl}$ at $4^{\circ} \mathrm{C}$ and found that at this temperature L. monocytogenes grew in all $\mathrm{NaCl}$ concentrations tested but there is decrease in population occurred at $12^{\text {th }}$ day of storage.

In another study carried out by Larson et al. (1999), it was found that L. monocytogenes inoculated into commercial cheese brines with $\mathrm{NaCl}$ content ranging from 5.6\% to $24.7 \%$ survived for long times (ranged from $<7$ days to over 259 days). This result was explained that the commercial cheese brines are mostly used repeatedly, and the proteins 
and other nutrients from cheese are APHA (2001): Compendium of Methods for accumulated in brines, which consequently makes the brine a nutrient-rich environment for L. monocytogenes. For this reason, In this study we replaced the formed curd in preautoclaved newly prepared brines in each time we repeated the experiment to put aside the effect of the brine accumulated nutrients or pathogen contamination on the survival of L.monocytogenes in different salt concentrations during storage time and to imitate as possible the traditional manufacture method and recipes to evaluate its efficiency in destruction of $L$.monocytogenes.

From the results mentioned above it is evident that the growth rate of $L$.monocytogenes was significantly decreased with increase of sodium chloride concentration and decrease of temperature of storage. In this regard other authors agreed with the obtained results that sodium chloride when exceeded $20 \%$, survival of $L$.monocytogenes not exceeded 5 days (Marth, 1993).

In conclusion the results of this study highlighted that using different concentrations of $\mathrm{NaCl}$ (Zero \%, 10\%, 15\% and $20 \%$ ) during manufacturing of soft white cheese proved that the high level of $\mathrm{NaCl}$ concentration (20\%) was completely effective in eliminating the pathogen from the experimentally contaminated cheese when stored at $4^{\circ} \mathrm{c}$ for 15 days.

\section{REFERENCES}

AbdAlla, O.M.; Christen, G.L. and Davidson, P.M. (1993): Chemical composition of and Listeria monocytogenes survival in white pickled cheese. J. food protection 56 (10) 481-836.

Abd El-Salam, M.H.; Alichanidis, E. and Zerfirididis, G.K. (1993): Domiati and feta-type cheeses. In: Fox PF (ed.) Cheese: Chemistrym Physies and Microbiology. Vol. 2.London: Chapman \&Hall, pp: 301-336. the Microbiological Examination of Foods. Frances Pouch Downes and Keith Ito. (eds.). $4^{\text {th }}$ Edition. Edwards Brothers, Washington, DC. USA.

Bille, J. and Glauser, M.P. (1988): "listeriose en swisse. Bulletine de 1 office de la Sante Publique 3, 28-29. (cited after Harver and Gilmour, 1992).

Dominguez, L.; Garayzabal, J.F.F.; Vazquez, J.A.; Blanco, J.L. and Suarez, G. (1987): Fate of Listeria monocytogenes during manufacture and ripening of semi-hard cheese.Lett. Appl. Microb. 4(6), 125-127.

Donnelly, C.W.; Briggs, E.H. and Donnelly, L.S. (1987): "Comparison of heat resistance of listeria monocytogenes in milk as determined by two methods. J. Food Prot., 50: 14

Durmaz, H.; Aygun, O. and Ardie, M. (2008):

The effect of cheese brine concentrations on survival of Listeria monocytogenes. Internet J. of Food Safety, vol. 10, 34-38.

Durmaz, H.; Aygun, O. and Ardic, M. (2009): The effect of cheese brine concentration on survival of Listeria monocytogenes. J. of Food Agriculture \&Enviroment, 7: 3/4, 11-13.

FDA (2003): U.S. Food and Drug Administration. Bacteriological Analytical Manual Online: Detection and enumeration of Listeria monocytogenes in foods. Available at: http://www. cfsan.fda.gov/ ebam/bam10.html. Accessed May 2006

Fleming, D.W.; Cohi, S.L.; Macdonald, K. L.; Brondum, J.; Hayes, P.S.; Plikaytis, B. D. and Reeingold, A.L. (1985): "Pasteurized milk as a vehicle of infection in an outbreak of listeriosis. Engl. J. Med. 312 (7): 404-407.

Gameiro, N.; Ferreiro-Dias, S.; Ferreiro M.; and Brito, L. (2007): Evolution of Listeria monocytogenes populations during the ripening of naturally contaminated raw ewes milk cheese J. Food Control, 18: 1258-1262. 
Hall, R.L. (1997): "Food brone illness implications for the future Emerging infection Diseases, 3: 555-559.

Harver, J. and Gilmour, A. (1992): "Occurrence of Listeria species in raw milk and dairy products produced in Northern Ireland. J. Appl. Bacteriol. 72 (2): 119-125.

Hassan Nour, M.K. (1996): Incidence of Listeria monocytogenes in milk and some dairy products. Ph.D.Veterinary Medicine, Cairo University.

Hefnawy, Y.A. and Marth, E.H. (1993): Survival and growth of L.monocytogenes in broth supplemented with sodium chloride and held at 4 and $13{ }^{\circ} \mathrm{C}$. Lebensmittel Wissenschaft and Technologie 26, (5): 388-392. Dairy Sci. Abst. 56 (5) 323 (1994).

Ibanez, M.D.C.; Martin-Alvarez, P. and Cabezas, L. (1993): Proteolysis in gruyere de comte cheese accentuating the effect of traditional salting. Revista Espanola de Cienciay Tecnologia de Alimentos. 33: 501-516.

James, S.M.; Fannin, S.L.; Agee, B.A.; Hall, B.; Parkerm, E.; Vogt, J.; Run, G.; Williams, J.; Lieb, L.; Salminen, C.; perndergast, T.; Werner, S.B. and Chin, J. (1985): "Listeriosis outbreak associated with Mexican-syte cheese. Morb. Mort. Wk. Rep., 34: 357-359.

Kaufmann, U. (1990): Behaviour of L. monocytogenes in raw milk- hard cheese. Revue Suisse d" Agricultre 22(1): 5-9, Dairy Sci. Abst., 54 (9)753. (1992).

Laborda, M.A. and Rubiolo, A.C. (1999): Proteolysis of fynbo cheese salted with $\mathrm{Nacl} / \mathrm{Kcl}$ and ripened at two temperatures. J. Food Sci. 64: 33-36.

Larson, A.E.; Johnson, E.A. and Nelson, J.H. (1999): Survival of L.monocytogenes in commercial cheese brines. J. of Dairy Sc., 82: 82, 1860-1868

Leuschner, R.G.K. and Ielsch, (2003): Pipova, M.; Soltesova, L.; Kottferova, J.; Antimicrobial effects of garlic,clove and red hot chilli on L.monocytogenes in broth model systems and soft cheese.
International J. of Food Sc. and Nutritions 54, 127-133. 27.

Leuschner, R.G. and Boughtflower, M.P. (2002): Laboratory-scale preparation of soft cheese artificially contaminated with low levels of Escherichia coli O157, Listeria monocytogenes, and Salmonella enterica serovars Typhimurium, Enteritidis, and Dublin. J. Food Prot. 65: 508-514. 26.

Lund, B.M. (1990): "Prevention of food borne

Marth, E.H. and Ryzer, E.T. (1990): Occurrence of Listeria in foods: milk and dairy foods. In Foodborne Listeriosis. Topics in industrial microbiology, Vol. 2, 151-164, USA. Dairy Sci.Abst., 54 (3) 228-229.(1992).

Marth, E.H. (1993): Growth and survival of L.monocytogenes, Salmonella species and Staphylococcus aureus in the presence of Sodium chloride. Dairy Food Environ. Sanit. 13 (1) 14- 18.

Miller, AJ.; Call, JE. and Eblen, BS. (1997): Growth, injury, and survival potential of Yersinia enterocolitica, Listeria monocytogenes and Staphylococcus aureus in brine chiller conditions. Journal of Food Protection. 60: 1334-1340.

Mullet, A.J.; Call, J.E. and Eblen, B.S. (1999): Growth, injury, and survival potential of Yersinia enterocolitica, Listeria monocytogenes and Staphylococcus aureus in brine chiller condition. J. of food protection 60: 1334-1340.

Papageorgiou, D.K. and Marth, E.H. (1989): Behaviour of Listeria monocytogenes at 4 and $22{ }^{\circ} \mathrm{C}$ in whey and skim milk containing 6 or $12 \%$ sodium chloride. J. of food Protection 52: 625-630.

Pearson, L.J. and Marth, E.H. (1990): L. monocytogenes - threat to a safe food supply: A review. Journal of Dairy Science 73: 912-928.

Laciakova, A.; Placha, I. and Giretova, M. (2002): The occurrence of Listeria monocytogenes in raw milk and its listeriosis. Br. Food J. 92, 13-22. 
survival under various storage pathogenic microorganism in la sereva condition. Folia Veterinaria.46:2,59-60 cheese throughout ripening J. Food

Ray, B. (1984): reversible freeze -injury. In Prote. 56, 872-881.

repairable lesions in microorganisms. Schuchat, A.; Swaminathan, B. and Broome, (Eds. P.A. and Nasim A.) pp. 237-271. New York, Academic Press.

Ryser, E.T.; Marth, E.H. and Doyle, M.P. (1985): Survival of Listeria Taormina, P.J. (2010): Implications of salt monocytogenes during manufacture and storage of cottage cheese. J. Food. Protect. 48(9): 746-750.

C.V. (1991): "Epidemiology of human listeriosis. Clin. Microbial. Rev. 4: 169-183.

and sodium reduction Critical Reviews in Food Science and Nutrition. 2010. 50: 3, 209-227. 184 ref.

Sanchez-Rey, R.; Poullet, B.; Caceres, P. and Tawfik, N.F. (1993): Growth and inactivation Larriba, G. (1993): "Microbiological quality and incidence of some of L. monocytogenes in Damiatti cheese. Egypt. J. Dairy. Sci. 21(1)1-9. 